\title{
Beyond the Lens: Kemi Adetiba's King of Boys as A Metaphor for Power and Order in Democratic Nigeria
}

\author{
Oluwafemi Sunday Onifade ${ }^{1^{*}}$ \\ ${ }^{1}$ Department of Mass Communication, Federal Polytechnic Bauchi, Bauchi, Nigeria \\ Bauchi-Tafawa Balewa, Bauchi, Nigeria \\ Email: onifadefemi@gmail.com
}

\begin{abstract}
This study examines the symbolic representations of Nigerian social reality in the movie "King of Boys". Social reality in this instance is examined from the perspective of official and unofficial political and economic power, influence and coercion. Based on the framework of Ferdinand de Saussure and Charles Sanders Peirce's semiotics and semiology theory, the study aims to examines the symbolic relationship between characters, scenes, and institutions in the Kemi Adetiba's "King of Boys" and the realities in the Nigerian political and security sectors. Using the methodological approach of Critical Discourse Analysis, the study found that the movie is a bold attempt at representing the intricate power relations that exists within Nigerian political circles as well as that which exists between the Nigerian political class and organized crime.
\end{abstract}

Keywords: Nigerian politics, nollywood, semiotics, corruption.

\begin{abstract}
Abstrak
Studi ini meneliti representasi simbolik dari realitas sosial Nigeria dalam film "King of Boys". Realitas sosial dalam hal ini dikaji dari perspektif kekuatan politik, pengaruh dan paksaan politik dan ekonomi baik secara resmi maupun tidak resmi. Berdasarkan kerangka kerja semiotika dan semiologi teori Ferdinand de Saussure dan Charles Sanders Peirce, penelitian ini bertujuan untuk menguji hubungan simbolik antara karakter, adegan, dan institusi di film "King of Boys" Kemi Adetiba dan realitas politik dan sektor keamanan Nigeria. Dengan menggunakan pendekatan metodologis dari Analisis Wacana Kritis, penelitian ini menemukan bahwa film tersebut merupakan upaya berani untuk mewakili hubungan kekuasaan yang rumit yang ada dalam lingkaran politik Nigeria serta yang ada antara kelas politik Nigeria dan kejahatan terorganisir.
\end{abstract}

Kata kunci: politik Nigeria, nollywood, semiotika, korupsi. 


\section{INTRODUCTION}

Democracy is arguably the dominant paradigm of government in the world. It is the yardstick for measuring the success or failure of governments. Democracy is widely perceived as a form of government in which every adult member of a society participates in the daily governance of the society either directly or indirectly through elected representatives.

In the practical sense, democracy as practiced in the developing world is far from the ideal concept. The will of the people is rarely evident in the processes and outcomes of the democratic process in the developing world. The ideas and manifestoes of candidates or parties carry little weight in the opinion of the electorates; instead, the amount of money expendable by each candidate or party as well as the control of the official and unofficial tools of coercion as well as the demonstrated ability to put them to "effective" use are more important in the estimation of the electorates and politicians (Samarzija 2020). The democratic experience of Nigeria since the return to democratic rule in 1999 suggests that the will of a few individuals trumps the wishes of the larger populace. For instance, a handful of political and economic elites have seemingly decided the flag bearers of the major parties and by extension, the occupiers of political offices. At the end of his second tenure in 2007, former president Olusegun Obasanjo singlehandedly installed late President Umar Yar'adua as his successor against the desires of other party leaders. At the regional level, former governor of Lagos State, Bola Tinubu has allegedly installed every governor of the state since he completed his second tenure in 2007.

The community is increasingly apparent through social media (Damayanti and Hidayat 2019). The media and the society have a symbiotic relationship. The nature, composition and content of the media is determined by societal dynamics and the media in turn influences social order through their representation of societal happenings. The movie industry is a subsidiary of the media industry and they reflect the social realities prevalent in any given geographical space.

In the submission of Adeleke, literature provides us with windows to life and films constitute an aspect of literary art. Movies therefore provide us windows into the socio-political and economic realities prevalent in the country. The pictures seen through the windows provided by movie producers and directors may be inaccurate due to the limitations imposed by the positions of the 
Onifade: Beyond the Lens: Kemi

Adetiba's King of Boys as A Metaphor

for Power and Order in Democratic

$\mathrm{N}$ igeria

filmmakers in relation to the general events happening in the social-cultural and political environment. However, they would always contain elements of the realities obtained in the society (Adeleke 2003).

Movies are representations of the world. Producers and directors draw inspiration from events around them and tell stories about such events from their own perspectives for the entertainment or enlightenment of their viewers. They provide their own interpretation of events in the society through their camera lenses. However, the lens can only see what is placed in front of it. This indicates that the camera lens does not provide a full picture or complete context for the images it presents to the world. Just like the camera lens, the human mind is also subjective and as such can only see and projects segments of reality at a time. The segments provided will depend on the ideological, social and experiential makeup of the person. It is against this background that producers and directors select and project information about the society to their viewers.

The media in every society provide reflections of such society (Mahmood 2016). They are products of the societies in which they operate and they have symbiotic relationship with the societies. A political internet use has been identified as a determinant of democratic attitudes (Stoycheff 2020). Communication has been identified as the underlying factor for human development whether at the socio-scientific, socio-economic or socio-political levels (Omoera and Obekpa 2019). Movies are powerful literary genre with the potential to "create profound changes in cultural values, norms, patterns and ideals of a nation and can alter the future of the nation. In fact, this feature makes the film industry today are closely connected with the politics" (Mohamadi 2016). Movie producers must therefore understand that they are public agents with obligations to their societies. They should therefore make conscious efforts to meet the expectations of their audience within the global context without necessarily devaluing their indigenous customs. Nigerian movie makers can serve as catalysts for socio-economic and political growth and development if they increase their knowledge of their immediate environment in relation to the larger world. This increase in knowledge can only be achieved through intensive and expansive research (Adeleke 2003) 
Movie is a complex and powerful genre of art which holds the potential to help us develop better understanding of ourselves in relation to the world around us. Films "can shed light on political and spiritual matters too and can provide catharsis and perspective and may open our eyes to new ways of thinking, feeling and pursuing our lives" (Mahmood 2016).

Movies are cultural products used to capture and preserve history. They reflect the prevailing political and socio-economic paradigms prevalent in the environment and era of their production. Some films are made to relive a time in history for the benefit of generations who were not born at the time the events happened. Kunle Afolayan's October $1^{\text {st }}$ and Biyi Bandele's Half of a Yellow Sun are examples of such movies. While October $1^{\text {st }}$ relives the intra-cultural, intercultural, racial, gender and class struggles that permeated the Nigerian political space at independence, Half of a Yellow Sun replicates the same issues as they relate to the Nigerian civil war otherwise known as the Biafran war.

The nature of films as historical documents divides opinion because history itself is inherently divisive as there are usually many accounts to every event and it is difficult for one account to capture every twist and turn in the historical plot (Endong 2019). Therefore, films that are meant to replicate history or mirror the society are likely to divide opinions due to the innate and experiential differences among humans. Notwithstanding the divisive nature of history and historical/critical films, the camera lens remains a convincing means for the preservation of cultural heritage and the interpretation of social-political events. KemiAdetiba'sKing of Boys fits this frame.

Movies are cultural products often with deeper messages than the words and actions heard and seen in the scenes. They provide room for subtle criticism of government programmes, policies, institutions and officials. The Nigerian senate is presently considering a bill to silence critics of the Nigerian state especially social media critics. With such bills in place, critical movies become more important in our understanding and evaluation of happenings in our society. Consequently, there is a need for media literacy on the part of everyone. Media literacy refers to the "ability to effectively and efficiently comprehend and use any form of mediated communication". It encapsulates "people's understanding of what the media are, how they operate, what messages they are delivering, what roles they play in society, and how audience members respond to media 
Onifade: Beyond the Lens: Kemi

Adetiba's King of Boys as A Metaphor

for Power and Order in Democratic

$\mathrm{Nigeria}$

messages" (Hanson 2014). People with high media literacy can easily decode the embedded messages in media productions while people with low media literacy can only see what is placed on the surface.

The novelty in this paper, that it is arguable that Nigerian movie viewers largely watch movies for their entertainment and socialization values and they rarely engage in critical analysis of the contents of the movies they watch. We often take media literacy for granted even though the mass media is central to the definition of our lives. It is therefore important that we develop and improve our media literacy skills in order to improve our lives.

The movie King of Boys contains characters and plots which are similar to real persons, institutions and situations in the Nigerian polity. While there have been efforts by film makers, over the years, to represent the political realities in Nigeria, there has been a dearth of attempts by Nigerian scholars to investigate the relationship between Nigerian movies and prevalent political realities. Another peculiarity of this study is that it is the first to attempt to interrogate the relationship between the political class and the criminal world. This study therefore aims at identifying the direct similarities between the components of the movie "King of Boys" and real life characters and situations in the Nigerian political economic space.

\section{METHODS}

Theoretical framework work hinges on the theoretical foundation of Ferdinand de Saussure and Charles Sanders Peirce's semiotics theory. Apart from the communication field itself, the theory is commonly used as a reference in various fields such as philosophy, linguistic, arts and literature, archeology, architecture, mathematics and so on (Yakin and Totu 2014). The theory emerged in 1916 after the death of de Saussure in 1913 and Peirce in 1914. Although purists would rightly divide the field into two concepts, semiotics (attributed to Peirce) and semiology (attributed to de Saussure), there seems to be a consensus that the terms semiotics covers the approaches of de Saussure and Peirce.

Semiotics is a theoretical paradigm that largely explains the investigation of the meaning of visual communication. The central goal of semiotics is "reframing 
the study of language and meaning as the study of signs". Therefore words, actions, settings and other elements of movies are examined for their symbolic values outside the screen. The analysis is to interpret gestures, facial expressions, micro expressions, behaviors that accompany a particular speech / message that appear in a moment of extreme emotional tension (Alexandru 2014). The implication of this theory to the present study is that the characters, plot, subplots, institutions and other elements contained in the movie King of Boys would be rearticulated as symbolic representations of real life occurrences in the geographical space called Nigeria.

It is important to emphasize that the "relationship between the audience and the image is subjective. Each individual whether subconsciously or consciously develops an associated meaning with each image they see" (Tom 2014). Therefore it is possible to have degrees of differences between the ideas projected by the director and the ideas decoded by the audience. It is also possible to have variations in the degree of comprehension of the messages by the audience based on their individual experiences and intellect.

Media literacy is central to effective semiotic appreciation. It is often said that meaning resides in man and not in words. The meaning of media messages therefore depends on the receiver. If the receiver does not possess equivalent knowledge, experiences or competence as the sender, the intended message could be lost in transit. The media literacy skills of the receiver is therefore a determinant of the meaning of symbols and signs (Hanson 2014). People who are unskilled in media literacy will consider the superficial meaning of media content while their counterparts with adequate media literacy skills will interpret same media content from many perspectives in line with the inherent array of varieties of meanings (Goharipour 2019). Methodologies related to scenario building include, in one way or another, two phases, one oriented to the research of data and analysis, and the storytelling focused on communication (Carbonell, SánchezEsguevillas, and Carro 2017).

This methodological paradigm employed by this study is the Critical Discourse Analysis (CDA). It is an analytical paradigm that is interested in the demystification of ideologies "and power through the systematic and retroductable investigation of semiotic data". Data from social media offer us multimedia data brimming with multiple layers of meanings. Social media enable rapid-fire digital 
Onifade: Beyond the Lens: Kemi

Adetiba's King of Boys as A Metaphor

for Power and Order in Democratic

$\mathrm{N}$ igeria

communications. These communications are incredibly complex in content, form and meaning (Mikhaeil and Baskervillebc 2019). Semiotic data in this regard include writings, paintings, pictures, sculpture and audio-visual recordings. Critical Discourse Analysis allows researchers to take clear positions reflecting where their interests lay without neglecting the scientific methodology. As Van Dijk puts it, Critical Discourse Analysis is a dissident research which allows analysts and researchers to take "explicit positions" in their quest to "understand, expose, and ultimately resist social inequality". Therefore this study shall reveal the position of the researcher on power and order in Nigeria as represented in the movie under review. On a superficial level, Discourse Analysis provides a framework for the analyses of national identity through the selection of different forms of text and talk.

Critical Discourse Analysis is favoured for this study because it is a method of research which primary focuses on "the way social power abuse, dominance, and inequality are enacted, reproduced, and resisted by text and talk in the social and political context". It focuses on how language influences power and how power influences the use of language within a social context. By focusing on the relationship between power and language use, CDA "reveals the way discourses are used ... for the development of new knowledge" (Taiwo 2007). Another reason for the selection of Critical Discourse Analysis for this study is that it is "anchored in social reality and with a deep interest in actual problems and forms of inequality in societies". Therefore, the use of Critical Discourse Analysis for this study will help to provide the historical, contextual and social backgrounds behind the textual narratives employed by the filmmakers. That inasmuch as misdemeanours, misappropriations, and questionable activities must be addressed by the media, it is equally important to acknowledge and commend the activities and events that are undertaken or embarked on to engender social change and development in Nigerian society (Nelson, Loto, and Omojola 2018).

The movie King of Boys is a 2018 political thriller directed by Kemi Adetiba. It is an attempt at representing the tumultuous world of Nigerian politics in motion picture. It attempts to establish the perceived link between the Nigerian political circle and the underworld. The movie centres on Alhaja Eniola Salami a 
successful underworld boss with close ties to the political elites. She purifies the money made from crime by investing in legitimate businesses like real estate, fabric shops and bakeries among others.

Realising that her political and economic significance in both the underworld and the political circle are unofficial, Eniola plays for an official appointive political position but she is schemed out of contention despite earlier assurances allegedly due to her strong ties to the underworld. Meanwhile her political dalliances have put a strain on her relationship with her lieutenants in the crime world. One of them breaks the "rule of engagement" and makes a play for her crown thus triggering a chain of events which brings Eniola Salami into conflict with the political class, institutions of state and segments of the underworld. She loses huge chunks of her political and economic clout in both the underworld and the legal world until cracks within the security and justice system enables her to escape albeit with scars. She finds her way to the United States of America and creates a new life as a small scale investor. Meanwhile, she rallies her banner men and foot soldiers in the underworld and reclaims her crown as the King of Boys directing the affairs of the "organization" from her hideout across the Atlantic.

Some of the themes in the movie are power, corruption, ambition and karma. The major lesson is that "evil will always self-destruct" (Tayo 2018). The movie was achieved using a powerful cast led by Sola Sobowale. Others are Adesuwa EtomiWellington, Demola Adedoyin, Jide Kosoko, Akin Lewis, Toni Tones and rapper Remilekun Safaru better known as "Reminisce". Comedian Seyi Law and Fuji music legend Wasiu Ayinde Anifowose better known as "K1 De Ultimate" also made guest appearances in the movie.

\section{RESULTS AND DISCUSSION}

The movie is a critical evaluation of Nigerian politics by Kemi Adetiba. Therefore, characters, settings, institutions portrayed in the movie are analysed for symbolic or metaphoric comparison to real life events, characters and institutions in Nigeria.

The ethnic dynamics of crime and law enforcement in Nigeria. Voter education campaigns often aim to increase political participation and accountability 
Onifade: Beyond the Lens: Kemi

Adetiba's King of Boys as A Metaphor

for Power and Order in Democratic

$\mathrm{Nigeria}$

(Fafchamps and Vicente 2013). A general observation is that the movie reinforces the widespread belief that ethnic groups in southern Nigeria are the biggest players in organized crime while the Hausa/ Fulani is the defender of the Nigerian socio-economic space. Nigerians of Yoruba and Igbo extraction are arguably the most travelled ethnic groups in the world. Their best make positive impacts in their sojourns while their worst dent the image of Nigeria abroad. Recently, the American Federal Bureau of Investigation (FBI) released a list of Nigerian crime syndicate with a global network and the list is populated by Southern Nigerian names. However recent killings and kidnappings in the northwest challenge the widespread notion that Yoruba and Igbo criminals are more sophisticated than their Hausa and Fulani counterparts. The face of crime fighting in Nigeria is Abbah Kyari (A Deputy Commissioner of Police) who heads the Inspector General of Police Intelligence Response Team. Although his team members cut across ethnic groups, they are often inconsequential in the estimation of the public.

The politics of Nigerian anti-corruption crusade. The Movie also replicates the dominance of the Nigerian security space by the northern region. They illustrate that transparency is a complex social process by highlighting the means by which the government tries to gain control of the NEITI organisation and how NEITI's ability to operate effectively is dependent on the political will of the government in power (Ejiogu, Ejiogu, and Ambituuni 2019). Detective Nurudeen Gobir is the symbol of anti-corruption in the movie. He is the star staff of the Nigerian Corruption Crime commission (NCCC). He is from the northern part of the country in the movie just like the all the leaders of Nigeria's foremost anticorruption agency the Economic and Financial Crimes Commission (EFCC) (Song, Chang, and Gong 2020). He also reports to another Hausa/Fulani man (Inspector Shehu) in the movie.

Since the creation of the EFCC, it has been headed by northern Nigerians. The first is NuhuRibadu, he was succeeded by Farida Waziri, who was replaced by Ibrahim Lamorde. The incumbent Ibrahim Magu succeeded Lamorde at the inception of the Buhari presidency. It is important to note that both Ibrahim Lamorde and Ibrahim Magu were pioneer staff of the EFCC under NuhuRibadu. 
In the movie, the NCCC is portrayed as a tool for settling political scores and it is ironically headed by corrupt men who care more about their pockets than the interest of the nation. This is similar to the perception of the EFCC by Nigerians. Over the years, the EFCC has allegedly harassed the opponents of the ruling elites while turning a blind eye to the crimes of the allies of the ruling elite. The Chairman of the ruling All Progressives Congress (APC) publicly stated that defectors to his party will be forgiven their sins (Nwogu, Onojeghen, and Peter 2019).

Corruption unarguably permeates every sector of Nigerian public life. Money meant for basic infrastructure are shared among the political class. Public office is the fastest means of making money in Nigeria, thus many people would do anything to get there (Onifade and Abati 2019). Corruption fuels political violence and those hired to mete out the violence on opponents would turn around to use the weapons on ordinary citizens after elections. In the movie under review, the party Chairman reportedly lost 45 million United States Dollars to the men of the underworld but he could not officially report the theft because the money was part of the fund he stole. This is a representation of the discovery of abandoned cash across the country at the commencement of President Buhari's presidency. Corruption also exists in anti-corruption agencies. Nigeria needs more effective and strong mechanisms proactive to curb corruption practices and weak institutional quality (Ojeka, Adegboye, Adegboye, Umukoro, Dahunsi, and Ozordi 2019). As seen in the movie, Inspector Gobir was setup for failure by his boss who was a tool in the hands of corrupt politicians. In the real world, all Chairmen of the Economic and Financial Crimes Commission EFCC have been accused of corruption. Nuhu Ribadu, Farida Waziri and Ibrahim Lamorde were all removed unceremoniously. The incumbent head, Ibrahim Magu, has been an Acting Chairman following the refusal of the last Senate to confirm him over allegations of corruption.

Elective and appointive positions are not attained on merit but on parochial considerations in Nigeria (Aregbeshola 2016). For instance, in the build up to the last general elections, many aspirants sought the gubernatorial ticket of the All Progressives Congress in Ogun State but the negative influence of godfathers led to changes in their political ambitions. Senator Solomon Olamilekan Adeola returned to contest for a senatorial seat in Lagos State, Barrister Biyi Otegbeye 
Onifade: Beyond the Lens: Kemi

Adetiba's King of Boys as A Metaphor

for Power and Order in Democratic

Nigeria

and Kola Lawal Mobolorunduro emerged as Federal House of Representatives candidates for rival parties and Tolu Odebiyi was redeployed to a senatorial contest. These changes were largely facilitated by three godfathers. They are Senator Bola Tinubu (who is the national leader of the APC), Chief Segun Osoba (a former governor of Ogun State) and Senator Ibikunle Amosun (the immediate past governor of Ogun State). Similar situations played out in other parts of the country across party line. In the movie King of Boys, Eniola Salami was promised a ministerial position in recognition of her services to the party but the godfathers changed their minds along the line. As a compensation, her son was pencilled for a cabinet position at the state level.

The haphazard allocation of political offices by godfathers in Nigerian democratic space is a long practice. In Oyo State, the late Lamidi Adedibu allegedly singlehandedly allocated all relevant elective and appointive offices in his state. In Kwara State, the Late Abubakar Olusola Saraki held sway in the allocation of offices until he was "defeated" by his son Bukola Saraki in the 2011 general elections. The son Bukola then took over as the de facto godfather of Kwara politics until his candidate lost in the 2019 general elections. In Lagos State, Asiwaju Bola Tinubu has been the undisputed godfather since his days as governor (1999-2007). He has since spread his tentacles to other south-western states as well as Kogi and Kwara states (states with sizeable number of Yoruba speaking tribes) with mixed results.

The outcome is that there is pseudo order in the polity as anointed candidates do the bidding of the political godfathers. Sovereignty and loyalty are taken away from the people and handed over to the godfathers. Only those who are willing to follow orders, serve and protect the interests of the godfathers are enthroned and they are changed as soon as they attempt to dislodge the godfathers (Derboven, Roeck, and Verstraete 2012). The case of the immediate past governor of Lagos State, Akinwunmi Ambode aptly fits in here. Although he is widely perceived to have performed well in the estimation of the electorates, he fell out with the godfathers of Lagos politics when he attempted to wean himself off them. He was promptly discredited in the court of public opinion and he was replaced by another candidate on the prodding of the godfather of Lagos politics, Bola Tinubu. 
A similar case is playing out in Edo State where Governor Godwin Obaseki is having a running battle with his benefactor and predecessor Adams Oshiomole. Mr Oshiomole who is the current national chairman of the ruling All Progressives Congress is the immediate past governor of Edo State and he installed Godwin Obaseki as his successor against the wishes of many stakeholders in the state. Upon assumption of office, Governor Obaseki has made efforts to rid himself of the shadow of Adams Oshiomole and they have been having running battles since then with many sordid revelations entering the public sphere from both camps. Nigerian policy has been shaped by such factors as: (1) interest group politics (based more on ethnic and regional than class cleavages), (2) the nation's legacy as a former British colony, (3) the shift in structure from being a colony to an independent nation, (4) the level of economic development, and (5) the structure of the labor force (Williamson and Pampel 1991).

Nigerian criminals are becoming increasingly sophisticated. They have learnt how to convert crime proceeds into legitimate income. In the movie under examination, Alhaja Eniola Salami "purifies" her ill-gotten money by investing in chains of legitimate businesses which include real estate, fabric shops, bakeries, water bottling companies among others. Self-acclaimed thugs in Nigeria like Sunday Igboho are known to be wealthy men with investment in real estate. Even notorious kidnapper Chukwudumeme Onwuamadike (popularly known as Evans) has substantial real estate investments in Nigeria, Ghana and South Africa.

Many Nigerian politicians are facing money laundering charges. While some have been convicted, many have been in court for long periods. James Ibori, Joshua Dariye and Orji Uzor Kalu are some of those convicted of embezzlement and money laundering while Danjuma Goje, Dieziani Alison Madueke, Walter Onnoghen, Ayo Fayose, Attahiru Baffarawa and Gbenga Daniel are among those who have been facing investigation and trial.

Synergy between crime and politics. Areas which were constituted into states have recorded development which may be directly attributed to the factor of their having been constituted into separate political sub-units (Ikporukpo 1986). The filmmaker established a link between politics and crime in the King of Boys. Eniola Salami and her likes were expected to provide funds and thugs for electoral victory. They were also expected to make their money from the black market economy without hurting the political elites. There are reports of association 
Onifade: Beyond the Lens: Kemi

Adetiba's King of Boys as A Metaphor

for Power and Order in Democratic

$\mathrm{Nigeria}$

between Nigerian government officials and suspected or convicted criminals "many of whom have been re-integrated into society without proper penance for their crimes".

In Nigerian politics, there are links between criminals and politicians too. Recently, a notorious kidnapper and political thug, Hamisu Bala Wadume was arrested and upon interrogation he to have received six million naira from a sitting governor. He also claimed to have received 13 million naira from the All Progressives Congress to prosecute the 2019 gubernatorial election in Taraba State. While one is likely to dismiss the claim of a criminal against a governor and the ruling party, the manner of his escape from custody after an initial arrest by men of the Nigerian Police Force suggests that he has powerful backers.

Following his arrest, he was being transported to Abuja by policemen when some soldiers ambushed the convoy and killed three of the policemen escorting him to Abuja thereby facilitating his escape. According to the kidnapper, the soldiers freed him from his handcuffs before he ran away. Also in neighbouring Benue State, an aide to Governor Samuel Ortom was arrested for being the mastermind of several killings across the state in 2018 (Ogundipe 2018).

Meanwhile governors of Sokoto, Zamfara and Katsina States negotiated peace deals with bandits operating in the north-west geopolitical zone. The governors "and the Inspector General of Police entered into discussions with the leaders of the bandits and reached some agreements" (Alike, Sardauna, Shiklam, and Innocent 2019). The peace deals is similar to that given to militants in the Niger-Delta region. The governor of Katsina State, Aminu Bello Masari said that the negotiations were yielding results as the negotiation had brought them relative peace (Pulse.ng 2019). The open admission of the deals with criminals shows that there is a collaboration between the state and the underworld for social order and stability.

Nigerian political and economic elite can get away with any crime. Whenever they are investigated, they are rarely indicted and when they are indicted, they either enter a plea bargain or face unending trials in court. In Nigeria, economic poverty is rooted in political poverty, since political actions set the pace for economic activities, and where political actions are driven more by 
personal caprice than by economic realities (Iyoboyi 2012). Some anti-corruption cases in Nigeria are up to ten years old. Former governors like Gbenga Daniel, Danjuma Goje and Ayodele Fayose are examples of members of the political class with perennial corruption cases in Nigerian courts. In the movie, the fate of the party chairman and Eniola Salami indicates that the rich and powerful will always have their way. Pressure from outsiders as groups within a state or as the state in its dominant ideological form is the main driver of ethnic political mobilization (Isumonah 2015).

Civil and public servants are used as pawns by the political elites. They use and discard them as soon as they outlive their usefulness. In the movie, Inspector Shehu was used by the party chairman and Eniola Salami at different times. He committed suicide to avoid the attendant shame that would have followed exposure of his sordid deals. Like the political stretegies that usually used ini political democracy in nigeria are ideologies and identities as persuasive strategies by candidates and political parties (Oluwamayowa, Gbadegesin, and Onanuga 2019). Nigeria is characterised by an (1) exclusive drug policy-making process, (2) repressive policy implementation and (3) strong bonds to foreign drug agencies (Klantschnig 2016).

\section{CONCLUSION}

Power and social order are complex societal issues. They are even more complex in emerging democracies like Nigeria. The movie King of Boys is a bold attempt at simplifying the complex realities of political power and social order in Nigeria. While it is impossible to provide the complete picture, the filmmaker's creation of characters, institutions, themes and contexts within the movie is not wide off the mark of the political and security realities obtainable in Nigeria. The movie has largely carried out the media functions of surveillance and correlation of social issues and it has shown that there is a relationship between Nigerian politicians and men of the underworld. Consequently, the degree of order obtainable in the country is dependent on the power relations between the political class and the organized crime world. The characters and scenes in the movie are semiotic materials which have represented the political and social realities obtainable in Nigeria. While the literarily conscious mind may see the relationship between the actions, themes, characters and properties in the movie and the 
Onifade: Beyond the Lens: Kemi

Adetiba's King of Boys as A Metaphor

for Power and Order in Democratic

$\mathrm{N}$ igeria

realities in Nigerian politics, those who are less perceptive may miss the similarities. This buttresses the position of de Saussure and Sanders that the relationship between the audience and the semiotic data is subjective. This means that while some viewers would only perceive the entertainment value of the movie, others would see beyond that and perceive the political, cultural, economic, and historical messages embedded in the movie. While it is arguable that the movie has preserved contemporary Nigerian political culture for future generations. It is important that other film makers tell stories about Nigerian political realities from their own perspectives so that viewers can have a variety of angles from which they could understand the complexities on Nigerian politics.

\section{REFERENCES}

Adeleke, Durotoye A. 2003. "Culture, Art and Film in an African Society: An Evaluation." Nordic Journal of African Studies 12(1):49-56.

Alexandru, Pompiliu. 2014. "A Semiotic Analysis of the Expression of Antithetical Emotional States." Journal Procedia - Social and Behavioral Sciences 149:31-36.

Alike, Ejiofor, Francis Sardauna, John Shiklam, and Onuminya Innocent. 2019. "Two Months after, Sokoto, Zamfara, Katsina Count GAins of Amnesty for Bandits." Thisday Newspaper.

Aregbeshola, Bolaji Samson. 2016. "Institutional Corruption, Health-Sector Reforms, and Health Status in Nigeria.” The Lancet Journal 388(10046):757.

Carbonell, Javier, Antonio Sánchez-Esguevillas, and Belén Carro. 2017. "No TitleFrom Data Analysis to Storytelling in Scenario Building. A Semiotic Approach to Purpose-Dependent Writing of Stories.” Futures Journal 88:1529.

Damayanti, Nur Laili and Medhy Aginta Hidayat. 2019. "Hiperreality Of Social Media: A Phenomenology Study of Self Confession of Housewives of Facebook Users." The Journal of Society and Media 3(2).

Derboven, Jan, Dries De Roeck, and Mathijs Verstraete. 2012. "Semiotic Analysis of Multi-Touch Interface Design: The MuTable Case Study." International Journal of Human-Computer Studies 70(10):714-28. 
Ejiogu, Amanze, Chibuzo Ejiogu, and Ambisisi Ambituuni. 2019. "The Dark Side of Transparency: Does the Nigeria Extractive Industries Transparency Initiative Help or Hinder Accountability and Corruption Control?" Journal : The British Accounting Review 51(5).

Endong, Floribert P. 2019. "Documenting Nigeria's Social and Cultural History Through Cinema: A Study of Biyi Bandele's Half of a Yellow Sun and Kunle Afolayan's October 1." IGI Global Website.

Fafchamps, Marcel and Pedro C. Vicente. 2013. "Political Violence and Social Networks: Experimental Evidence from a Nigerian Election." Journal of Development Economics 101:27-48.

Goharipour, Hamed. 2019. "Narratives of a Lost Space: A Semiotic Analysis of Central Courtyards in Iranian Cinema." Journal of Frontiers of Architectural Research 8(2):164-74.

Hanson, Ralph E. 2014. Mass Communication: Living in a Media World. Lost Angeles: Sage Publication.

Ikporukpo, C. O. 1986. "Politics and Regional Policies: The Issue of State Creation in Nigeria." Journal of Political Geography Quarterly 5(2):127-39.

Isumonah, Victor Adefemi. 2015. "Minority Political Mobilization in the Struggle for Resource Control in Nigeria." Journal of The Extractive Industries and Society 2(4):645-53.

Iyoboyi, Martins. 2012. "The Political Economi of Poverty in Nigeria." International Journal of Research in Commerce, Economic and Management 2(8).

Klantschnig, Gernot. 2016. "The Politics of Drug Control in Nigeria: Exclusion, Repression and Obstacles to Policy Change." International Journal of Drug Policy 30:132-39.

Mahmood, Istiak. 2016. "Influence and Importance of Cinema on the Lifestyle of Educated Youth: A Study on University Students of Bangladesh." IOSR Journal of Humanities And Social Science 77-80.

Mikhaeil, Christine Abdalla and Richard L. Baskervillebc. 2019. "Using Semiotics to Analyze Representational Complexity in Social Media." Journal of Information and Organization 29(4).

Mohamadi, Fateme. 2016. "Making a Sociological Inquiry about the Role of Films in Lifestyle." International Journal of Research in Humanities and Social Studies 3:44-56. 
Onifade: Beyond the Lens: Kemi

Adetiba's King of Boys as A Metaphor

for Power and Order in Democratic

$\mathrm{N}$ igeria

Nelson, Okorie, Grace Loto, and Oladokun Omojola. 2018. "Blogging, Civic Engagement, and Coverage of Political Conflict in Nigeria: A Study of Nairaland.Com.” Kasetsart Journal of Social Sciences 39(2):291-98.

Ogundipe, Samuel. 2018. "Governor Ortom Speaks as Army Arrests Aide for 'Masterminding' Benue Killings." The Premium Times, April 18.

Ojeka, Stephen, Alex Adegboye, Kofo Adegboye, Olaoluwa Umukoro, Olajide Dahunsi, and Emmanuel Ozordi. 2019. "Corruption Perception, Institutional Quality and Performance of Listed Companies in Nigeria." Journal of Heliyon 5(10).

Oluwamayowa, Gbadegesin, Victoria, and Paul Ayodeye Onanuga. 2019. "The Enactment of Ideology and Self-Presentation in Political Campaign Videos of the 2015 General Election in Nigeria." Journal of Discourse, Context and Media 28:121-30.

Omoera, Osakue Stevenson and Enuwa Evelyn Obekpa. 2019. "Neo-Colonial Dependence and Dualistic Development Models: An Exploration of the Development Communication Trajectory in Nigeria." The Journal of Society and Media 3(2).

Onifade, Oluwafemi. S. and Mobolaji. O. Abati. 2019. "Rearticulating Corruption: An Assessment of Selected Newspapers' Narratives on Atiku Abubakar's Strategic Foreign Trips." Sub-Sahara African Journal of Humanities and Social Science 161-72.

Pulse.ng. 2019. "Katsina Governor Says Negotiation with Bandits Yielding Results." Pulse.Ng, September 22.

Samarzija, Snjezana Prijic. 2020. "The Epistemology of Democracy: The Epistemic Virtues of Democracy.” Journal : Filozofija i Drustvo 31(1):5670.

Song, Chang-Qing, Chun-Ping Chang, and Qiang Gong. 2020. "Economic Growth, Corruption, and Financial Development: Global Evidence." Economic Modelling Journal.

Stoycheff, Elizabeth. 2020. "No TitleRelatively Democratic: How Perceived Internet Interference Shapes Attitudes about Democracy." The International Journal of Press/Politic.

Taiwo, Rotimi. 2007. "Language, Ideology and Power Relations in Nigerian Newspaper Headlines.” Nebula Journal 218-45. 
Tayo, Ayomide O. 2018. "King of Boys Is a Movie That Nollywood Needs Right Now." Pulse.Ng.

Tom, Eileen W. 2014. "Social Constructs in Film Culture: The Effect of It on the Performing Arts, and the Destroyed Association of Signs to Enhance Meaning." Portland State University.

Williamson, John B. and Fred C. Pampel. 1991. "Ethnic Politics, Colonial Legacy, and Old Age Security Policy: The Nigerian Case in Historical and Comparative Perspective." Journal of Aging Studies 5(1):19-44.

Yakin, Halina Sendera Mohd. and Andreas Totu. 2014. "The Semiotic Perspectives of Peirce and Saussure: A Brief Comparative Study." Procedia Journal - Social and Behavioral Sciences 155:4-8. 